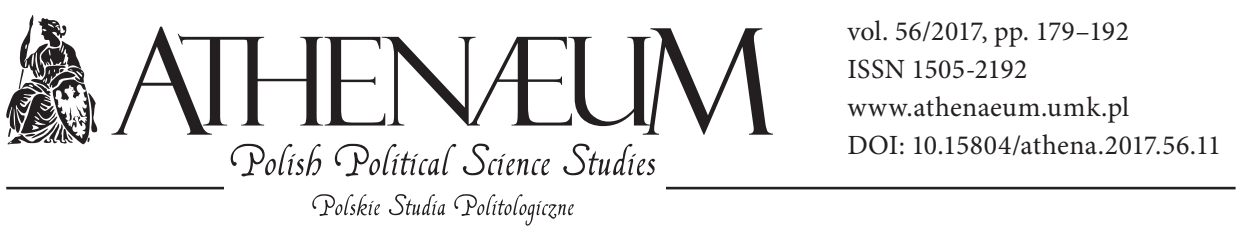

\title{
IDENTITY ISSUE IN INTERNATIONAL RELATIONS: CONSTRUCTIVIST APPROACH
}

\author{
ZAGADNIENIE TOŻSAMOŚCI W NAUCE O STOSUNKACH \\ MIĘDZYNARODOWYCH - UJĘCIE KONSTRUKTYWISTYCZNE
}

Anna Skolimowska*

\begin{abstract}
Constructivist approach of analyzing international relations brought many new elements to the thought on the nature of international reality, which made it possible to explain it and understand it better. One of these elements in the process of analyzing this reality is the concept of identity of participants of international relations. Its analytical phenomenon consists of the fact that it allows us to undertake attempts to understand interests and character of norms and values of participants of international relations. The most important statement brought to scientific thought on international reality by Alexander Wendt's notion of constructivism relates to the fact that states' interests in international relations are not given a priori, but they are shaped during interactions with others. Not only is the role of inter-state actors who influence states' interests in international relations underlined, but it also indicates the important role of other participants of international affairs in articulating national interests. From this perspective, the category of identity in international relations taken up
\end{abstract}

Konstruktywistyczna perspektywa analizowania relacji międzynarodowych wniosła wiele nowych elementów do refleksji nad naturą rzeczywistości międzynarodowej, pozwalając na jej lepsze rozumienie oraz wyjaśnianie. Jednym $\mathrm{z}$ takich elementów w procesie analizy tej rzeczywistości jest koncept tożsamości uczestnika relacji międzynarodowych. Jego fenomen analityczny polega na tym, iż pozwala on podejmować próby zrozumienia interesów oraz specyfiki norm i wartości, którymi kierują się uczestnicy relacji międzynarodowych. Najbardziej istotne twierdzenie, jakie wprowadza do naukowej refleksji o rzeczywistości międzynarodowej konstruktywizm w wariancie Aleksandra Wendta, odnosi się do faktu, iż interesy państw w relacjach międzynarodowych nie są z góry dane, ale kształtują się w toku interakcji z innymi. Podkreśla się tutaj zatem rolę nie tylko aktorów wewnątrzpaństwowych, którzy mają wpływ na kształtowe przez państwa interesy w relacjach międzynarodowych, ale także wskazuje się na istotną rolę pozostałych uczestników obrotu międzynarodowego w arty-

* Cardinal Stefan Wyszyński University in Warsaw, Faculty of History and Social Sciences. 
by Constructivism takes account of the social, interactive nature of international reality making it possible to analyze its intangible part.

Keywords: social constructivism, identity, social construction of reality, linguistic turn, International Relations kułowaniu interesów narodowych. Z tego punktu widzenia podejmowana przez konstruktywizm kategoria tożsamości w relacjach międzynarodowych uwzględnia społeczną, interaktywną naturę rzeczywistości międzynarodowej, pozwalając analizować jej niematerialną warstwę.

Słowa kluczowe: konstruktywizm społeczny, tożsamość, społeczne tworzenie rzeczywistości, zwrot językowy, stosunki międzynarodowe

\section{INTRODUCTION}

Since the $1980^{\mathrm{s}}$ studies on International Relations (IR) pay increasing attention to the identity issue of participants of international relations. However, there is no coherent definition of this concept. In spite of that, it is more and more often used by researchers together with the constructivist turn in the International Relations. In this aspect the concept and the phenomenon of identity of participants of international relations is an inherent element necessary to explain and understand interests of states in international relations and to explain continuity and variability of this reality. Following the thought of Alexander Wendt, one of the most prominent representatives of Constructivism in IR, it is claimed that state's interests are shaped by their identities which change with time, and the natural phenomenon of identity more and more increasingly becomes a subject of scientific thought (Wendt, 2008).

The aim of this analysis is to evaluate scientific value of Constructivism in explaining international relations - especially the identity issue. This goal will be achieved by answering following questions: What is the nature of the concept of identity in the International Relations? What is the explanatory value of this phenomenon? Does Constructivism and the ideal of identity proposed by it enables explanation of the international reality?

Popularity of identity issue in the International Relations derives from the growing popularity of Constructivism among theoreticians of international relations during last three decades. It allows researchers to analyze the intangible aspects of the political reality such as: norms, values, discourses or ideas and also the phenomenon of identity, which is a peculiar product of these intangible elements. The interest in the aspect of identity in the science of International 
Relations may also derive from a peculiar socialization of the thought on the international reality. The socialization of the science of International Relations was to make studies more focused on the social context of international politics. Representatives of the Constructivism (Alexander Wendt, Nicholas Onuf, Friedrich Kratochwil) questioned both ontological and epistemological assumptions of previous theoretical approaches within the frames of the science of International Relations. They underlined importance of ideas, norms, institutions and identity for international politics and indicated correlations of agents and structures (Reus-Smit, 2006) .

It is assumed that Constructivism is best suited to explain identity issue in the International Relations among other approaches (i.e., Neorealism or Neoliberalism) due to its characteristics: ideational ontology and special attention to epistemological matters. "Social" character of the reflection on International Relations offered by Constructivism allows to undertake the reflection on soft elements of international reality like, i.a., identity issue.

The analysis will be made by using qualitative methods - by identifying the phenomena of identity in the works of the main representatives of Constructivism in International Relations: Alexander Wendt, Maja Zehfuss, Stefano Guzzini.

The article will be divided into three sections. The first one will touch upon the phenomenon of identity in Social Science in general. Genesis and way of its conceptualization will be shown. The second part of the article will be the analysis of the genesis and specificity of Constructivism in the IR. It will allow to point at the novel character of Constructivist explanation of international reality. The third part of the article will contain Constructivist way of explaining the identity issue in IR. Main works of Constructivist scholars will be presented.

This analysis makes it possible to understand of the theoretical thought on the phenomenon of identity within the frames of the science of International Relations and the importance of this concept for analyzing participation in the international relations.

\section{IDENTITY ISSUE IN THE SOCIAL SCIENCES}

Studying identity of international actors within the frames of the International Relations was preceded by theoretical activity undertaken by scholars of the Social Sciences in the United States not later than in $1960^{\text {s }}$ (Erikson, 1968). The concept of identity in Social Sciences is not unequivocal. Its content depends on 
the context. There are, however, some common traits of this concept (Brubaker, Cooper, 2000):

a) identity is understood as the base for political and social actions. Sometimes it is set against the category of interests in order to explain the non-instrumental reasons behind actions. The concept of identity is used in this context to underline the manner in which actions (individual or group actions) can derive more from self-understanding of the acting subject than from its purse of execute a specific interest;

b) identity understood as collective phenomenon - with this category an individual marks his/her similarity to others in the group. It can be understood as sameness itself deriving from characteristics of the given subject or as subjective feeling, experience or perceiving own similarity towards other members of the given group. Such identity reveals itself with the attitude of solidarity or common actions with other group members. From this perspective the difference between the concept of identity as an analytical tool and the social attitude is often unclear;

c) identity understood as a major aspect of functioning in a social or political group. Here it is perceived as something to be appreciated, preserved and protected;

d) identity as a result of social and political actions. This approach underlines the properties of identity being created in the process of social interactions. Therefore it is perceived in two ways. On one hand, as a product of social interactions and on the other, as an element necessary to undertake collective actions;

e) identity as a product of discourse practices - it is an effect of various, competitive discourses.

Several attributes of identity can be distinguished. Identity is something that people/social groups/states have or they pursue it or they should have it. It is a trait which meaning should be sought and discovered (Brubaker, Cooper, 2000).

Within the frames of the Social Sciences the concept of identity joins works on basic social categories such as: social class, race, ethnic background, sex, disability and sexuality, showing the connection between psychological and social processes in given societies or political communities ${ }^{1}$. The research on identity

1 Examples of such works are: M. Wetherell (ed.), Identity in the 21st Century. New Trends in Changing Times, Palgrave Macmillan, 2009; J. McLaughlin, P. Phillimore, D. Richardson (eds.), 
constitute basis for deeper thoughts on the nature of new and appearing social and cultural forms, as well as the influence of globalization, trans-nationality, post-colonialism and multiculturalism on social and political processes.

\section{CONSTRUCTIVIST TURN IN THE INTERNATIONAL RELATIONS}

As mentioned above, the concept of identity started to be taken up by the science of International Relations in 1980s, together with increasing popularity of Constructivism in researches concerning this reality (Zehfuss, 2002, p.7).

Constructivism in the International Relations was an answer to changes in international reality in $1980^{\mathrm{s}}$ and 1990s: decrease of importance of state independence being a result of globalization processes, increasing economic and social importance of scientific knowledge, shift of power, etc. These facts made researchers understand that science does not depend on subjects it concerns but it rather shapes them. This statement was valid especially in the context of the Cold War, which was about to finish soon. Previous theories were neither able to predict the upcoming change nor understand its core later on. This cognitive pessimism of ontological background subsequently moved on to epistemological matters spreading doubt in the positivistic paradigm of science (Guzzini, 2000).

In the $1980^{s}$ and 1990s, together with the so-called Constructivist turn in the science of International Relations, the matter of identity of participants of international relations became increasingly taken up in the thought on the nature of international relations. The end of the Cold War was an explanation challenge for main theories of international relations, especially Neoliberalism and Neorealism. They were neither to predict it nor explain it. These difficulties, as shown by representatives of Constructivist turn, stemmed from their materialistic and individual orientation, which precluded wider perception of the ongoing changes - for example from the social perspective (Wendt, 2008). This kind of perspective would allow touching upon many more aspects of these processes. The need to "socialize" the theory of international relations constituted reasons for development of researches in the vein of Constructivism. This peculiar socialization of the science of International Relations was to pay more attention to the social context of international politics. Representatives of Constructivism (Alexander Wendt, Nicholas Onuf, Friedrich Kratochwil) questioned both ontological 
and epistemological assumptions of the foregoing theoretical approach within the frames of the International Relations. They underlined the importance of ideas, norms, institutions and identity for international politics and indicated correlation of agents and structures (Reus-Smit, 2006). The substance of the Constructivist turn in the International Relations was to abandon the foregoing theoretical assumptions, which were found insufficient for understanding the reality. The Constructivist perspective in the International Relations was inspired by changes observed in Social Sciences such as philosophy or sociology. Their aim was to build an alternative way between the existing theories (Skolimowska, 2013).

Constructivism assumes that the character of international relations can not be analyzed without its context. The analyzed elements are: beliefs, ideas, opinions, discourses. There are two standpoints within this approach. The first one, rooted in Humanities, refers to hermeneutics and phenomenology. It pursues understanding of the meanings that people relate to social activity. It assumes epistemological positivism and uses hermeneutical methods in researches. The second one is more radical - it rejects the cognitive positivism, even declaring scientific nihilism. The first standpoint is called poststructuralism, the second - postmodernism (Bevir, Rhodes, 2006).

The reason behind popularity of Constructivism in the science of International Relations in 1980s, mainly in the USA, was also connected to the geopolitical situation of those times. Not only the end of theories was declared then, but also the "end of history", as stated by Francis Fukuyama. The historical context (i.e., the end of the Cold War) and discussions among researchers of International Relations (especially Neorealists and Neoliberals) prepared ground for Constructivism, which became especially popular among researchers form the USA. Europe was dominated by the thought on International Relations developed by the English school, which analysis of interstate interactions focused on their roles in international relations.

The term "Constructivism" was introduced to International Relations theories by an American researcher Nicholas Onuf. He used it for the first time in his book World of Our Making: Rules and Rule in Social Theory and International Relations ${ }^{2}$ published in 1989. Other representatives of this strand are, i.a., Peter Katzenstein, Friedrich Kratochwil, and Alexander Wendt.

2 Nicholas Onuf is a retired professor of International Relations at the University of Florida. He is an author of: A Constructivist Manifesto, [in:] K. Burch, R.A. Denemark (eds.), Constituting Inter- 
The Constructivist perspective in International Relations states that the theory of international reality and its studies should be based on solid ontological and epistemological basis. Representatives of this strand ask new questions concerning the role of identity, norms in forming of national interests, character of processes of institutionalization and global management, and also the social construction of international regimes. The Constructivist debate within the frames of International Relations is held on the levels of metatheory and the theory of International Relations (Czaputowicz, 2016).

The genesis of Constructivism in the International Relations should be sought in the context of the third rationalism vs. reflectivism interparadigm debate, which related to theories in science. It concerned both ontological and epistemological matters. Due to that, researchers agree that it was the most important of all debates. The extreme positions were to be reconciled by Constructivism. That was Alexander Wendt's ambition. The appearance of Constructivism in the area of the science of International Relations was related to four factors: an attempt to reassess the concept of world theory and politics; the already mentioned inability of traditional approaches to catch the essence of changes in world politics at the end of $1980^{\mathrm{s}}$ and the beginning of 1990s; the appearance of a generation of young researchers, who spotted the necessity to change the foregoing paradigms (Reus-Smit, 2006).

The changes introduced to International Relations theory by Constructivism are called the "constructivist turn". Its essence is accepting positivistic epistemology together with inter-subjective ontology and opening epistemology to interpretationism. "Turn" in ontology consists in becoming open to ideation factors in researches of the international reality. Within the frames of the science of International Relations, Constructivism is not a unified strand. There are two basic strands of it: conventional and interpretative.

The conventional Constructivism, which dominates mainly in the USA, concentrates on the meaning of norms and identity in shaping the international politics (ideation ontology). Researchers of this strand assume the positivistic epistemological orientation stating the need to build bridges between different theoretical approaches. The research comprises mainly of quality and case-study

national Political Economy, London 1997, p. 7-18; Constructivism: A User's Manual, [in:] V. Kubálková, N. Onuf, P. Kowert (eds.), International Relations in a Constructed World, London 1998, p. 58-78; Worlds of Our Own Making: The Strange Career of Constructivism, [in:] D. Puchala (ed.), Visions of International Relations, Columbia 2002, p. 119-141; Parsing Personal Identity: Self, Other, Agent, [in:] F. Debrix (ed.), Language, Agency, and Politics in a Constructed World, New York 2002, p. 26-50. 
methods. They assume that the truth about the world can be discovered through objective research procedure. They are theoretically inspired by sociology, institutionalism and theory of organization. They do not pay much attention to meta-theoretical matters. They use the so called process tracing method in their research ${ }^{3}$. This strand is represented, i.a., by Jeffrey Checkel, Joseph Jupille, James Caporaso.

Interpretative Constructivism is most popular in Europe. It deals with the matter of language in shaping the social reality. The main analytical category here is the power of discourse. From epistemological perspective these researchers refer to post-positivism. They ask questions concerning possibility of a certain event happening. For example: instead of the question on what factors caused interests of a state in international relations to be changed, the Constructivists concentrate on the background of the event and on language constructions (discourse) which accompanied the change. In their researches they refer to induction methods and focus on the process of reconstruction of the state's interests in international relations. They concentrate on the language matter in the context of reproduction of identity in the social world. These Constructivists use the method of discourse analysis. They are theoretically inspired by language studies performed on the base of the social theory, i.a., by the following researchers: Jürgen Habermas, Pierre Bourdieu, or Jacques Derrida (Checkel, 2006).

All this shows that constructivism is not a unified standpoint: it is divided between those who perceive constructivism as a tool either for explaining or understanding the international reality (Wiener, 2006).

The above typology also proves that within the science of International Relations, Constructivism differs not only in the subject aspect, but also in the object one - due to the research tradition in which it is embedded. However, in the Anglo-American tradition of Political Sciences, Constructivism has the positivistic form. Researches of this strand state possibility to reach objective truth about the reality constructed socially with empirical research methods. Cognition here has the form of explaining the reality.

The continental (European) tradition in Political Sciences Constructivism has the post-positivistic form. Researchers of this strand deny the existence of

\footnotetext{
3 It is a research method in which a researcher accompanies the researched phenomenon to discover its hidden meanings. Using this method helps to identify the process, i.e., mechanisms and relations among independent variables and the effect of dependent variables. Process tracing forces the researcher to consider alternative ways leading to the given phenomenon taking place - this method offers possibility to draw more than one possible way of evolution of the given phenomenon.
} 
objective truth about the reality, as it is influenced by subjective understanding and interpretations. Language is the only tool which makes it possible to reach it. Cognition here has the form of understanding the reality.

Constructivists claim that majority of, or even all significant elements in international politics result from detailed social conditions and historical processes, not from inevitable consequences deriving from human or society nature. The most well known contemporary constructivists are: Nicholas Onuf (World of Our Making: Rules and Rule in Social Theory and International Relations, 1989), Alexander Wendt (Social Theory of International Politics, 1999), John Ruggie (Constructing the World Polity: Essays on International Institutionalization, 1998), or Martha Finnemore (National Interests in International Society, 1997).

Constructivists state that the objective social reality does not exist. The social and political world are intangible objects and they do not exist outside of human consciousness. The international system is not anything external towards a person. It exists as inter-subjective awareness among people, it is a product of a man and has ideational character. It constitutes a set of ideas, a collection of thoughts, a system of norms developed by specific people in specific place. Inter-subjective character of international relations enables studying them with scientific methods, both in positivistic and post-positivistic sense (Jackson, Sørensen, 2012).

Constructivists use analytical categories from the areas of sociology, psychology or philosophy, which widens the theoretical discourse within the area of the science of International Relations ${ }^{4}$. Using such sources causes the fact that the Constructivists' thought naturally concentrates on individuals and groups rather than on states, international organizations or other actors of international politics. It is thanks to Constructivism that the international reality started to be perceived and studied in the categories of social reality. Assumptions of constructivism are as follows:

- international relations comprise mainly of ideas and norms; tangible factors play less important role (ontological idealism);

- the following are the ideation elements: inter-subjective opinions (ideas, concepts), for example: awareness of being a nation, considering own state as independent, sense of group identity, own political institutions; these opinions create and express interests and identity;

4 Before, the main inspiration for researchers of international relations were: law, natural science, or economy. 
- the social world is not given and it does not belong to the world of nature; the world is created by man; knowledge on it can be obtained through explaining or understanding (epistemological positivism and postpositivism; Jackson, Sørensen, 2012).

Within the science of International Relations, Constructivism has been best developed by the American political scientist Alexander Wendt in his work entitled: Social Theory of International Politics. It is divided into seven parts including sociological and philosophical analysis of the social construction of international reality - the core of Constructivist perception of international relations.

Wendt's thesis are based on criticism of opinions of Kenneth Waltz, the author of Theory of International Politics (1979), which includes synthesis of Neorealism, and Robert Keohane, the author of After Hegemony (1984), who is considered to be the father of contemporary Neoliberalism in the theory of international relations.

Regarding the basic Neorealistic paradigm, Wendt indicates errors in this type of thinking. He claims that it too hastily rejects the fact that states are causative subjects, they have human traits as intentionality, rationality, interests. Neoliberals in turn quickly reject the opinion that international relations are state-oriented, which leaves space for adversaries of Neorealism.

The second part of Wendt's book concerns the process of international politics. The author claims that this structure is created, reproduced and even modified under the influence of interactions among its states. The author calls them agents of international politics (Wendt, 1987). The model of these interactions assumes that states (as entities with anthropomorphic traits such as: interests, identity, needs, desires) choose specific behavior as response to external stimulus. It leads to their identity becoming real and subsequently to establishing their interests and consequently to choosing a specified behavior. The author indicates four factors which can lead to changes in relations among states within the structure. These are: co-dependence, homogenization, self-limitation, and community of fate.

Neorealists and Constructivists agree that states strive to survive and be safe. But what form of security policy derives from it? Do states try to become as powerful as possible, or they are rather satisfied with what they have? Wendt states that we can learn it by studying identity and interests, because they are shaped as results of interactions among states, which create group meanings being a construction according to which the future activities are organized. Through participation in this structure, actors can better understand their identities, role in the system and expectations towards them. 


\section{IDENTITY ISSUE IN CONSTRUCTIVISM}

The following analysis identifies the manners for explaining the phenomenon of identity from the perspective of works by Alexander Wendt. It also seeks an answer to the question on the manner of understanding identity, its role in international relations and strategies of constructing it. It shows differences in explaining this phenomenon from the perspectives of different variants of Constructivism. One of the assumption of Constructivist theory is: states construct each other through interactions. The main thesis of Wendt is: the character of identities and interests of states depends on interactions among them. Structures of identities and interests are created during these interactions.

The idea of identity in international relations derives from social psychology, especially from the theory of social identity. According to it, social groups define themselves basing on sets of ideas. The ideas can be articulated directly through a discourse or indirectly by common symbols, codes or signs. The purpose of these ideas is to create a definition of the given social group as a community separate from other groups. Members of such group are convinced about the existence of common base on which they create "imagined community" (Marcussen, Risse, Engelman-Martin, Knopf, Roscher, 2001).

Alexander Wendt, who is considered to be the main representative of Constructivism in the science of International Relations, claims that identity is a subjective court existing at the level of an individual, which has its roots in actor's self-understanding. The importance of this understanding depends on the fact if other actors present the actor in the same manner (Wendt, 2008). Therefore identity comprises of two types of ideas: self perception and perception of others towards the given subject. In this aspect identity is constituted by structures internal and external towards the given subject. A. Wendt list several types of identity:

a) personal or corporate - such identities are constituted by self-organizing structures which make actors distinctive subjects;

b) concerning the type - identity which exists integrally with an actor and depends on the actor's traits (depends on the states political system, for example democratic states, monarchies, etc.);

c) concerning the role - it is identity which can exist only in relation with others, because it is the others that legitimatize it and give meaning to it;

d) collective (Keohane, 1984) - such an identity is related to the process of identification, i.e., considering self-image in the eyes of others during the process of constructing own identity. 
The concept of identity of participants of international relations introduced by A. Wendt constitutes a revolution in the scope of understanding interactions among subjects of international relations. It assumes that identity is developed, supported and changed in the process of interactions among them, and international relations themselves are socially constructed (Wendt, 1999). Therefore identities also have variable and fluxional character depending on the character of participants of international relations in the given time and place.

Wendt also indicates the existence of the phenomenon of corporate identity, which he relates to a set of internal traits which self-organize the given political community. These are: individuals acting in the given community, physical resources, opinions and institutions (Wendt, 1994). A. Wendt classified identities by two different identities: corporate identity and social identity. Corporate identity is intrinsic and self-organizing identity that constitutes actor individuality. It is motivational energy to engage in action or interaction. The corporate identity of the state generates four basic interests: (1) physical security, (2) ontological security in relationships to the world, which create a desire for stable social identities 5 , (3) recognition as an actor by others, above and beyond survival, (4) development for better life at the collective level. On the other hand, social identity is cognitive and structural things which enable an actor to determine "who I am/we are" in a situation and positions in a social role structure of shared understandings and expectations. Social identities and interests are always in process during interaction.

Thus societal structures constitute identities as characteristics of actors, and the actors form their own interests on this basis: "Identities are the basis of interests" (Wendt, 1992).

Collective identity is a positive identification with the welfare of other. This is based on solidarity, community, and loyalty. This discourages free-riding by increasing diffuse reciprocity and the willingness to bear costs without selective incentives. Collective identity is different from an alliance, which is temporary coalition of self-interested states in response to a specific threat. Collective identity makes multilateral actions against non-specific threats by diffusing reciprocity and increasing the willingness to act on "generalized principle of conduct".

5 Ontological security is understood as constant feeling of identity: being aware of aims, preferences and interests, which in turn gives possibility of further actions in the international environment. 
There are three types of mechanisms that promote collective identities at the systemic level: Structural contexts, Systemic processes, and Strategic practice.

\section{CONCLUSION}

The issue of identity of participants of international relations (and states - in relation to the analysis) has become a subject of scientific thought especially within the frames of development of the Constructivist paradigm in the International Relations. Explaining the phenomenon of interactions among participants of international relations within Constructivism has made it possible to see the process-like and variable character of identity. Constructivism, especially the conventional one, represented by A. Wendt, provides approach to the intangible aspect of international relations, which had not been available to researchers within the scope of traditional paradigms.

\section{ReFERENCES:}

Bevir, M., Rhodes, R A.W. (2006). Teoria interpretacjonistyczna. In: D. Marsh, G. Stoker (eds.), Teorie i metody w naukach politycznych (p. 131-152), Kraków: Wydawnictwo Uniwersytetu Jagiellońskiego.

Brubaker, R., Cooper, F. (2000). Beyond "Identity”. Theory and Society, 29(1), 1-47.

Checkel, J. (2006). Constructivist Approaches to European Integration. ARENA Working Papers, 6. Retrieved from: http://www.arena.uio.no/publications/workingpapers2006/papers/wp06_06.xml.

Czaputowicz, J. (2016). Zastosowanie konstruktywizmu w studiach europejskich. Warszawa: Wydawnictwo Uniwersytetu Warszawskiego.

Erikson, E. (1968). Identity: Youth and Crisis. New York: W.W. Norton Company.

Guzzini, S. (2000). Reconstruction of Constructivism in International Relations. European Journal of International Relations, 6(2), 147-182.

Jackson, R., Sørensen, G. (2012). Wprowadzenie do stosunków międzynarodowych. Teorie i kierunki badawcze. Kraków: Wydawnictwo Uniwersytetu Jagiellońskiego.

Keohane, R. (1984). After Hegemony: Cooperation and Discord in the World Political Economy. Princeton: Princeton University Press.

Marcussen, M., Risse, T., Engelman-Martin, D., Knopf, H.J., Roscher, K. (2001). Constructing Europe? The Evolution of Nation-State Identities. In: T. Christiansen, K.E. Jørgensen, A. Wiener (eds.), The Social Construction of Europe (p. 101-121). London: Sage Publications. 
Reus-Smit, Ch. (2006). Konstruktywizm. In: S. Burchill [et al.], Teorie stosunków międzynarodowych (p. 269-296). Warszawa: Książka i Wiedza.

Skolimowska, A. (2013). Konstruktywizm w studiach europejskich. Warszawa: Oficyna Wydawnicza Łoś-graf.

Wendt, A. (1987). The Agent-Structure Problem in International Relations Theory. International Organizations, 41(3), 335-370.

Wendt, A. (1992). Anarchy Is What States Make of It: The Social Construction of Power Politics. International Organization, 46(2), 391-425.

Wendt, A. (1994). Collective Identity Formation and the International State. American Political Science Review, 88(2), 384-396.

Wendt, A. (1999). Social Theory of International Politics. Cambridge: Cambridge University Press.

Wendt, A. (2008). Społeczna teoria stosunków międzynarodowych. Warszawa: Wydawnictwo Naukowe Scholar.

Wiener, A. (2006). Constructivist Approaches in International Relations Theory: Puzzles and Promises. Constitutionalism Webpapers ConWEB, 5, p. 1-27. Retrieved from: https://www.wiso.uni-hamburg.de/fachbereich-sowi/professuren/wiener/ dokumente/conwebpaperspdfs/2006/conweb-5-2006.pdf.

Zehfuss, M. (2002). Constructivism in International Relations: The Politics of Reality. Cambridge: Cambridge University Press. 